In the recent Bucharest investigations, V. G. Bossie $^{2}$, working with wheat, shows that the cycle of absorption and migration is somewhat similar to that of barley, differing only in details. The life period of some seventy days in wheat can be divided into three phases: (1) vegetative, which reaches its maximum by the twenty-sixth day; (2) fruiting, which commences about the thirty-first day and culminates about the sixty-fifth day, and (3) postmaturity. Absorption of all mineral elements in the aerial portions as a whole was rapid and very considerable during phase (1); thereafter the rate of absorption of phosphorus, nitrogen and magnesium was markedly decreased, but none of these was lost, whereas in the case of potassium and calcium actual loss occurred after the first twenty-six days; silica, which amounts to nearly half the total ash, continued to be absorbed more or less regularly until maturity, when some loss of all elements occurred. The amount of the loss was most marked in the case of potassium and calcium, as negative migration of these had started early, but the loss in all other cases was less than 20 per cent. What is happening is that during the stage (2) the developing ear is drawing its supplies of nutrients from the leafy stems, silica only being absorbed directly from the soil; the supply of nitrogen, phosphorus and magnesium is inadequate in the leaves and so a further slight absorption of these elements from the soil takes place; potassium and calcium, however, are in excess of the amount required by the ear, and so can be returned to the soil.

The phenomenon of negative migration occurs in other groups of plants. In tobacco, for example, not only does loss of soil constituents occur when the main stem has reached maturity, but it may also be succeeded by re-absorption and further negative migration corresponding with the development of axillary shoots ${ }^{3}$.

It seems obvious, therefore, that the reason for the changes in the rate of absorption by the plant must be sought in the metabolic state of the tissues, and that when actual loss occurs it is probably due to the interaction of the factors causing the meta. bolic changes and the factors of the soil environment affecting absorption. In this respect it is well to mention that Burd ${ }^{5}$ found that the losses occurred in oats when the constituents of the water extracts of the soil were at or approaching their minima and when the same constituents were moving from the leaves to the ear.

It has been suggested that the elements migrating from the aerial organs are accumulated by the roots. In the paper by Bossie, however, details of the analyses of roots have been included, and bearing in mind the difficulties attending collection of these organs from the soil, the resuits show that this cannot be the case; for example, from the twentysixth day to the thirty-fifth day, the aerial organs of a hundred wheat plants lost $0.187 \mathrm{gm}$. of potassium, whereas the roots only accumulated $0.001 \mathrm{gm}$. in the same time; the other $0.186 \mathrm{gm}$. must therefore have been returned to the soil.

\section{N. L. Penston.}

${ }^{1}$ Deleanu, N. T., and Bordeianu, C., Acad. Roma. Mem. Sect. Stiint. Ser. 111, Tom. ix, Mem. 10 (1934), "Studiu asupra rolului si functiunil substantelor minerale si organice in viata plantei", No. 11.

${ }^{2}$ Bossie, V. G., Lab. de Chim. Anal. Facultatea de Farmacie, ibid., No. iv ; 1934 .

${ }^{3}$ Vladescu, I. D., Lab. de Chimie. Anal. Universitatea din Bucuresti, ibid., No. $\mathbf{2} ; 1934$

- Deleanu, N. T., Trav. de. l'Institut de Bot. Geneve, 1908.

s Burd, J. S., J. Agric. Res., 18; 1919.

- Jones and Huston, Ind. Expt. Sta. Bull., 175 ; 1914.

\title{
Third Imperial Mycological Conference
}

$\mathrm{I}^{\mathrm{N}}$ $\mathrm{N}$ spite of financial stringency, which has cramped the activities of many scientific institutions of recent years, the Imperial Mycological Institute organised a very successful Conference at the Imperial College of Science and Technology in September 1934. Invitations were conveyed to overseas Governments of the British Empire, to certain Government Departments of the United Kingdom, and to the staffs of agricultural and horticultural research stations, university departments, to individual mycologists, and to the representatives of certain firms interested in the manufacture of fungicides. A report of the activities of this Conference has recently appeared (Imp. Mycol. Inst., Kew, Surrey, pp. 32, 2s. net).

Sir Charles Howell Thomas opened the proceedings of the Conference on September 17. In the course of his speech of welcome, he referred to the change in administrative control of the Institute, and praised the work of Lord Buxton in fostering the efficient work of the Institutes of Mycology and Entomology before they were taken over by the Executive Council of the Imperial Agricultural Bureaux. The future finance of the Institute of Mycology gives cause for concern, and was the subject of deliberation by a special sub-committee. It was recommended that representations be made to the various Governments supporting the Institute for restored or increased financial aid.

The Director (Dr. E. J. Butler), in reviewing the work of the Institute, showed that enormous financial losses are sustained as a result of fungal attack, and stressed the importance of disease surveys in demonstrating such loss. He also discussed the publication of the Institute's periodical Review of Applied Mycology.

The deliberations of the Conference naturally covered a wide field. Administrative measures against plant diseases, methods of standardisation of insecticides and fungicides, virus diseases, control methods for small cultivators, foot-rots of cereals, breeding and selection for immunity against disease, and several papers on diseases of particular crops, formed the main topies.

One important activity of the Conference lay in the drafting of a health certificate to be given to consignments of plants made within the Empire. This is not designed to replace any legislation or quarantine regulations, and carries nothing but a hallmark of freedom from disease. If this practice is adopted extensively, it should mark a very considerable advance in the control of fungus diseases. 